\title{
DETERMINANTY WYKORZYSTANIA NARZĘDZI E-REKRUTACJI \\ W PRZEDSIĘBIORSTWACH \\ Z WOJEWÓDZTWA ZACHODNIOPOMORSKIEGO
}

DOI: 10.33141/po.2019.10.06

\author{
Wojciech Jarecki, Marek Kunasz
}

\section{Wprowadzenie}

$\mathbf{W}^{\mathrm{s}}$ współczesnej gospodarce zachodzą dynamiczne zmiany, związane $\mathrm{z}$ rozwojem Internetu, migracjami, globalizacją, które wpływają na funkcjonowanie przedsiębiorstw we wszystkich jego obszarach (Cichy, 2008, s. 17-42; Juchnowicz, 2007, s. 21-27). Jednym $\mathrm{z}$ takich ważnych obszarów jest zarządzanie kapitałem ludzkim, czyli wiedzą, doświadczeniem i umiejętnościami pracowników. Kluczowym jego elementem jest pozyskiwanie pracowników, obejmujące swoim zakresem rekrutację, czyli proces poszukiwania i nawiązywania kontaktu z potencjalnymi kandydatami, oraz selekcję, oznaczającą wybór, przy zastosowaniu adekwatnych narzędzi, potencjalnych pracowników.

Zmianie ulegają też rodzaje wymagań stawianych pracownikom. Oczekuje się od nich coraz większej samodzielności, kreatywności, odpowiedzialności, pracy zespołowej, umiejętności uczenia się, wczuwania w potrzeby innych osób, identyfikacji z przedsiębiorstwem, czyli coraz większej własnej aktywności w podnoszeniu kompetencji (Młokosiewicz, Misiak-Kwit, 2017, s. 79-81). We wspomnianym kontekście coraz większego znaczenia nabiera umiejętność pozyskania pracowników, a rozwój Internetu i mediów społecznościowych zwiększa spektrum możliwych do zastosowania instrumentów oraz podnosi efektywność realizowanych w tej sferze procesów.

Dotychczasowe badania w zakresie pozyskiwania pracowników do organizacji podejmują jedynie w ograniczonym zakresie kwestię uwarunkowań wykorzystania narzędzi rekrutacji, szczególnie narzędzi e-rekrutacji, co powoduje lukę badawczą w tym zakresie. Stąd też celem niniejszego artykułu jest określenie czynników determinujących wykorzystanie przez przedsiębiorstwa Internetu (bądź szerzej instrumentów e-rekrutacji) w poszukiwaniu pracowników na rynku pracy. Zrealizowano go przez analizę literatury przedmiotu, a także prezentację wyników badań empirycznych przeprowadzonych w ramach projektu badawczego "Aktywizacja zawodowa i badawcza Uniwersytetów Trzeciego Wieku” finansowanego ze środków Ministerstwa Nauki i Szkolnictwa Wyższego. Badania zrealizowano na próbie 203 przedsiębiorstw $\mathrm{z}$ województwa zachodniopomorskie- go. W pracy znalazło zastosowanie głównie instrumentarium modelowania ekonometrycznego. Szacowano modele logitowe ${ }^{1}$.

\section{Internet i media społecznościowe w procesie pozyskiwania pracowników - przegląd literatury}

D rzedsiębiorstwa funkcjonują $\mathrm{w}$ dynamicznie zmieniającym się otoczeniu. Obejmuje ono w szczególności gospodarkę, politykę prowadzoną przez państwo, rynek pracy, prawo, wyznawane wartości, ale przede wszystkim zmiany $\mathrm{w}$ technice i technologii, a w ostatnich 20-30 latach - w informatyce i Internecie (Schaupp, Bélanger, 2014, s. 187-195; Urbanowska-Sojkin, Weinert, 2019, s. 59-61; Olszak, 2018, s. 37-40; Jarecki, 2011, s. 29-30). Szczególnym wyzwaniem dla organizacji są te ostatnie zmiany, gdyż stawiają wysokie wymagania wobec wiedzy i umiejętności zarządzających oraz pracowników. W obliczu tych wyzwań stoją również osoby zajmujące się pozyskiwaniem pracowników do organizacji. Jest to zadanie złożone i odpowiedzialne, gdyż dotyczy tworzenia kapitału ludzkiego, który jest najcenniejszym zasobem organizacji, decydującym o jej rozwoju, zdolności konkurowania czy pozycji rynkowej.

Efektywna rekrutacja (dobór) pracowników oznacza, że z jednej strony zatrudniani są ci kandydaci, którzy tworzą szanse bardzo dobrego spełnienia oczekiwań pracodawcy w zakresie wydajności pracy i współpracy, a z drugiej, że osoby zatrudnione będą mogły realizować swoje oczekiwania, potrzeby zawodowe i społeczne, co wpływa na zadowolenie $\mathrm{z}$ pracy i życia, a w efekcie również przekłada się na rozwój pracownika i wydajność jego pracy.

Organizacje odnoszące sukcesy doskonale zdają sobie sprawę, że na wyszukiwanie kandydatów i ich selekcję należy ponosić koszty proporcjonalne do kompetencji, jakie kandydaci ci mają posiadać w stosunku do potrzeb wynikających z przyjętej strategii i wizji przedsiębiorstwa. Trafne decyzje rekrutacyjne zwracają się szybko w wydajności nowo zatrudnionej osoby, a często i całego już funkcjonującego zespołu. 
W tradycyjnej rekrutacji dotarcie do potencjalnych kandydatów dokonywało się poprzez już zatrudnionych pracowników, ich znajomych, gazety codzienne i czasopisma fachowe, targi pracy bądź informacje dystrybuowane w Powiatowych Urzędach Pracy. Takie instrumenty rekrutacji są nadal wykorzystywane, ale w coraz większym zakresie procesy te są wspierane przez Internet i media społecznościowe (Kiełtyka, Zygon, 2018, s. 37-40; Ihsan, Furnham, 2018, s. 147-166). Chodzi tu przede wszystkim o przekaz informacji drogą elektroniczną. Ma on różną postać: przesyłanych e-maili bądź odczytywanych informacji zawartych na portalach internetowych (w tym na portalach firmowych). W literaturze przedmiotu pojawił się termin e-rekrutacja, odnoszący się do procesu poszukiwania kandydatów (lub pracy - w przypadku osób fizycznych) przez sieć (Ngai i in., 2015, s. 33-44). Szczególnego znaczenia na rynku pracy nabrała zmiana dotycząca rekrutacji związana z wykorzystaniem mediów społecznościowych (Ouirdi i in., 2016, s. 240-249).

Zarządzających organizacjami można podzielić na korzystających i niekorzystających z mediów społecznościowych. W gronie tych drugich można wyróżnić pasywnych i aktywnych. Ci pierwsi zamieszczają ogłoszenia na profilach firmowych czy grupach (np. na Facebooku), drudzy szukają kandydatów poprzez portale internetowe, szczególnie poprzez LinkedIn i Goldenline, czyli dwa serwisy z wbudowanymi funkcjami poszukiwania pracy. Na tych portalach są zamieszczone indywidualne profile zawodowe, będące odpowiednikiem CV. Serwisy te umożliwiają wyszukiwanie i wybór kandydatów oraz nawiązanie z nimi kontaktu. Należy podkreślić, że korzystanie z portali umożliwia dotarcie również do tych kandydatów, którzy nie podejmują aktywnie działań na rzecz zmiany miejsca pracy, czy nawet tego na dany moment nie rozważają. Warto też przedstawić dane ilościowe $\mathrm{w}$ omawianym zakresie. Według portalu pracuj.pl aż 70\% osób z branży HR poszukuje na portalach społecznościowych informacji o kandydacie, jego kompetencjach i dotychczasowej karierze, jeszcze przed rozmową kwalifikacyjną (Mroczek, 2018). Z kolei z badań przeprowadzonych przez Lee Hecht Harrison DBM Polska wynika, że 97 proc. polskich rekruterów korzysta $\mathrm{z}$ mediów społecznościowych w swojej pracy. Codziennie robi to nawet $77 \%$ headhunterów oraz $35 \%$ rekruterów wewnętrznych (Kadry.infor, 2018). Z kolei dane GUS podają, że prawie $30 \%$ przedsiębiorstw zatrudniających powyżej 9 osób korzysta z serwisów społecznościowych (GUS, 2019, s. 1).

Dla kandydatów media społecznościowe stanowią ważne źródło wiedzy o ofertach pracy i potencjalnym pracodawcy. Według danych GUS, w 2018 roku 50\% osób w wieku 16-74 lata korzystało, w różnych celach, z serwisów społecznościowych (GUS, 2019, s. 2). Portale społecznościowe cieszą się ogromną popularnością wśród osób często korzystających z Internetu. Szacuje się, że około $75 \%$ spośród nich regularnie odwiedza i aktualizuje swoje profile $\mathrm{w}$ przynajmniej jednym ta- kim portalu, co może być dobrym źródłem wiedzy dla rekruterów (Kłosiński, 2018).

Można wskazać kilka zalet korzystania przez organizacje z Internetu i mediów społecznościowych w rekrutacji. Główną jest oszczędność czasu pracodawcy i kandydata. Pracodawcy wyszukują bowiem kandydatów jak najlepiej dopasowanych do ich wymagań bez konieczności przeglądania napływających do firmy CV. Kolejna korzyść to możliwy do pozyskania zakres informacji o kandydatach znajdujący się w tych mediach (np. Facebooku) (Frandsen i in., 2016). Przeglądając indywidualne profile kandydatów, można dowiedzieć się o ich zainteresowaniach, wartościach, osobowości, planach zawodowych i osobistych. Można też ocenić znajomość korzystania $\mathrm{z}$ Internetu i mediów społecznościowych przez kandydata, co jest obecnie coraz ważniejszą umiejętnością (Wielgórska, 2018). Warto uwzględnić to, że korzystanie $\mathrm{z}$ Internetu i mediów do rekrutacji daje możliwość dotarcia do większej liczby osób, do kandydatów o specyficznych kompetencjach, możliwość szybszego znalezienia kandydata, a to wszystko wpływa na osiągnięcie przewagi konkurencyjnej (Social Recruiting Guide, 2016). Niemniej należy przyjąć stanowisko, że media społecznościowe nie powinny być traktowane jako substytut tradycyjnej rekrutacji, lecz jako narzędzie komplementarne. Tym bardziej, że są też pewne wady i niedoskonałości wykorzystania Internetu i mediów społecznościowych w rekrutacji, np. ryzyko, że część aktywności w Internecie nie jest wykonywana bezpośrednio przez kandydata, a pewne zachowania, opinie kandydata, prezentowane w mediach społecznościowych mogą mieć minimalne znaczenie dla jego wydajności pracy i posiadanych kompetencji, natomiast mogą zaważyć na jego zatrudnieniu lub odrzuceniu oferty. Można też zauważyć, że aktywność w mediach nie musi oznaczać posiadania umiejętności dobrej komunikacji bezpośredniej $\mathrm{z}$ innymi, co jest bardzo przydatne w pracy zespołowej i w kontaktach z klientami oraz przełożonymi. Warto też jest mieć na uwadze to, że część osób nie korzysta z tych narzędzi, co nie oznacza, że nie dysponuje kompetencjami informatycznymi. Niebagatelne znaczenie, szczególnie dla budowania wizerunku firmy, mogą mieć zagadnienia etyczne związane $\mathrm{z}$ wykorzystaniem nowych narzędzi rekrutacji (Woźniak, Rafalik, 2018, s. 61-77) czy nadużywaniem informacji pozyskiwanych podczas rekrutacji (Lee, Rha, 2016, s. 453 -462; Wadle i in., 2019, s. 319-324). Pomijając tradycyjne kanały docierania do kandydatów i ich pozyskiwania, można pomiąć osoby o wysokich kompetencjach, szczególnie pracowników starszych, dysponujących wieloletnim doświadczeniem zawodowym (Smentek, 2007, s. 16).

\section{Metoda badawcza}

D rzedstawiona analiza dotychczasowych badań pozwoliła na sformułowanie problemu badawczego - określenie poziomu wykorzystania Internetu przez 
przedsiębiorstwa przy poszukiwaniu pracowników na rynku pracy. Jest to zagadnienie wymagające ciągłych badań, gdyż następuje szybki rozwój narzędzi możliwych do wykorzystania przez Internet, w tym $\mathrm{z}$ wykorzystaniem urządzeń mobilnych, a z drugiej strony wzrastają umiejętności obsługi tych urządzeń przez osoby w każdym wieku.

Dla skonkretyzowania i uściślenia problemu badawczego sformułowano 3 pytania szczegółowe:

1. Jaka jest struktura wykorzystywanych przez przedsiębiorstwa instrumentów rekrutacji?

2. W jakim stopniu badane przedsiębiorstwa wykorzystują instrumentarium e-rekrutacji przy poszukiwaniu pracowników na rynku pracy?

3. Jakie czynniki determinują wykorzystanie Internetu (instrumentarium e-rekrutacji) przez przedsiębiorstwa przy poszukiwaniu pracowników na rynku pracy?

W pracy wykorzystano materiał empiryczny zgromadzony $w$ ramach badań ankietowych przedsiębiorstw przeprowadzonych podczas realizacji projektu badawczego „Aktywizacja zawodowa i badawcza Uniwersytetów Trzeciego Wieku”. Projekt był realizowany przez Uniwersytet Szczeciński we współpracy z sześcioma Uniwersytetami Trzeciego Wieku (UTW) z województwa zachodniopomorskiego. Projekt został sfinansowany ze środków Ministerstwa Nauki i Szkolnictwa Wyższego w ramach programu wsparcia Uniwersytetów Trzeciego Wieku.

W każdym z ośrodków zaangażowanych w projekt powstały zespoły badacze (liczące od 4 do 6 studentów UTW) uczestniczące w procesie gromadzenia danych. Członkowie tych zespołów zostali odpowiednio przeszkoleni w zakresie realizacji badań naukowych. W zespołach tych konsultowano formularze ankietowe oraz przeprowadzono badania pilotażowe. Te działania realizowano w okresie marzec - kwiecień 2018 r. Zespoły badawcze zostały następnie zaangażowane $\mathrm{w}$ gromadzenie materiału empirycznego $\mathrm{z}$ rejonu działania danego Uniwersytetu Trzeciego Wieku. Działania w ramach wspomnianego etapu realizowano w okresie maj-czerwiec 2018 r. Badania miały charakter częściowy. W takim przypadku ze zdefiniowanej populacji (tę tworzyły przedsiębiorstwa $\mathrm{z}$ województwa zachodniopomorskiego) wyłania się próbę badawczą. Aby wyniki badań mogły zostać uogólnione na populację, próba badawcza musi być odpowiednio liczna i reprezentatywna. Reprezentatywność zapewnia losowość doboru jednostek do próby. Ankietę badawczą skierowano pocztą tradycyjną równolegle do 400 przedsiębiorstw Z województwa zachodniopomorskiego (w okresie majczerwiec 2018 r.). Zastosowano dobór warstwowo-losowy jednostek do próby ważony liczbą mieszkańców poszczególnych powiatów. Operat badawczy stanowiła lista przedsiębiorstw wpisanych do bazy danych rejestru podmiotów gospodarki narodowej (REGON).

Zgromadzony w ten sposób dwutorowo materiał empiryczny obejmował dane z 203 organizacji. Dane zakodowano w dedykowanym systemie komputerowym przygotowanym w arkuszu kalkulacyjnym MS Excel. Kwestionariusz ankiety obejmował łącznie 21 pytań ( $w$ tym pytania $\mathrm{w}$ metryczce). Zgodnie $\mathrm{z}$ przyjętymi założeniami i sugestiami w piśmie przewodnim ankietę $\mathrm{w}$ danym przedsiębiorstwie miała wypełnić osoba pełniąca najwyższe funkcje w strukturze zarządzania bądź odpowiedzialna za sferę personalną. Strukturę próby opisano w punkcie prezentującym wyniki badań przy okazji prezentacji wykazu zmiennych objaśniających $\mathrm{z}$ modelu.

\section{Wyniki badań}

$\mathbf{R}$ espondentom przedłożono pytanie o instrumenty, jakie reprezentowane przez nich przedsiębiorstwo wykorzystuje w procesach rekrutacyjnych, wraz z 7 wariantami możliwych odpowiedzi (oraz wariantem pozwalającym na wskazanie innych stosowanych instrumentów rekrutacji). Jeden $\mathrm{z}$ wariantów odpowiedzi obejmował rekrutację z wykorzystaniem Internetu (ogłoszenia w Internecie). Pozostałe warianty odnosiły się do instrumentarium tradycyjnego. Każdy respondent (ze względu na ograniczenia systemu obróbki danych) mógł wybrać maksymalnie trzy warianty odpowiedzi.

W tabeli 1 zaprezentowano strukturę deklaracji respondentów w odpowiedzi na przywołane pytanie. Określono odsetek wskazań danej opcji w ogóle wskazań respondentów (wskaźniki struktury sumują się zatem do $100 \%)$.

Tabela 1. Narzędzia rekrutacji stosowane w badanych przedsiębiorstwach (dane w \%)

\begin{tabular}{|l|c|}
\hline \multicolumn{1}{|c|}{ Narzędzia rekrutacji } & $\%$ \\
\hline ogłoszenia w Internecie & 29,3 \\
\hline pośrednictwo znajomych i rodziny & 21,9 \\
\hline pośrednictwo urzędów pracy & 19,9 \\
\hline ogłoszenia w prasie & 14,4 \\
\hline analiza ofert przychodzących do firmy & 6,1 \\
\hline kontakt z agencją pośrednictwa pracy & 5,4 \\
\hline targi pracy & 2,0 \\
\hline inne & 0,9 \\
\hline
\end{tabular}

Źródto: opracowanie własne

Ogłoszenia w Internecie były opcją najczęściej wybieraną przez respondentów. Objęły 29,3\% ogółu wskazań wykorzystywanych przez badane podmioty instrumentów rekrutacji. Obok instrumentarium internetowego przedsiębiorstwa korzystały $\mathrm{z}$ pośrednictwa innych osób (np. znajomych) bądź urzędów pracy. Najrzadziej wykorzystywanym spośród instrumentów przedstawionych respondentom do wyboru okazało się uczestnictwo $\mathrm{w}$ targach pracy. 
W badaniach zaprezentowanych $\mathrm{w}$ dalszej części opracowania dla określenia czynników determinujących wykorzystanie Internetu przez przedsiębiorstwa (instrumentarium e-rekrutacji) przy poszukiwaniu pracowników na rynku pracy wykorzystano instrumentarium modelowania ekonometrycznego. W przypadku badań ankietowych gromadzących deklaracje respondentów w odpowiedzi na stawiane pytania możliwe jest zakodowanie odpowiedzi do układu zero-jedynkowego. Uzyskane w ten sposób dane można odzwierciedlić na skali nominalnej odmiennie przyporządkowując obiekty do danej grupy (np. kobieta, mężczyzna). W takim przypadku zastosowanie znajdują modele logitowe (Osińska, 2007; Welfe, 2009; Górecki, 2010; Kufel, 2011; Gruszczyński, 2012; Maddala, 2013). W modelach tych określa się związki pomiędzy zmienną objaśnianą i zestawem zmiennych objaśniających $\mathrm{z}$ uwzględnieniem jednakże specyficznej transformacji logitowej zmiennych. Interpretacji nie podlegają wartości współczynników przy zmiennych. Taką rolę przejmuje głównie iloraz szans odzwierciedlający prawdopodobieństwa sukcesu w rozpatrywanej grupie oraz grupie wzorcowej (referencyjnej). Wartość ilorazu szans powyżej jedności wskazuje na relatywnie większe szanse na sukces $\mathrm{w}$ danej grupie i odwrotnie. Specyficznie w modelach tej klasy szacuje się parametry przy zmiennych objaśniających - metodą największej wiarygodności, stosuje się także specyficzne miary oceny jakości oszacowań.

W pracy oszacowano dwa modele ekonometryczne. Niezbędne obliczenia wykonano w programie Gretl. W obu przypadkach zmienna objaśniana kodowana była na podstawie odpowiedzi respondentów na przedstawione powyżej pytanie o instrumenty, jakie badane przedsiębiorstwa wykorzystują $\mathrm{w}$ procesach rekrutacyjnych. Kodując zmienną objaśnianą, uwzględniano wybory respondentów dotyczące opcji „ogłoszenia w Internecie”, dzieląc próbę przedsiębiorstw na grupy podmiotów stosujących (1) bądź niestosujących (0) tego typu instrumentarium.

Ze zmienną objaśnianą powiązano zestaw zmiennych objaśniających. W przypadku modelu $1 \mathrm{w}$ analizach wyodrębniono czynniki, które mogą różnicować szanse badanych podmiotów na stosowanie instru- mentarium rekrutacji $\mathrm{z}$ wykorzystaniem Internetu. Specyfikację zmiennych objaśniających włączanych do modelu 1 zaprezentowano $\mathrm{w}$ tabeli 2. Przedstawiono w niej kolejno nazwę kategorii zmiennych objaśniających, liczbę włączanych w danej kategorii zmiennych - grup respondentów. Następnie w ramach każdej kategorii wyspecyfikowano wyodrębnione grupy respondentów (rozpatrywane jako zmienne) z podziałem na grupy referencyjne (w stosunku do których porównywano wyniki dla innych grup $\mathrm{w}$ danej kategorii - porównania dotyczyły ilorazów szans, dla grupy referencyjnej iloraz szans wynosi 1, zaś wpływ tej grupy w modelu odzwierciedlony został w wyrazie wolnym) oraz pozostałe - uwzględnione w modelu.

Do analiz włączono 15 grup respondentów wyodrębnionych na podstawie 5 kryteriów podziału (realizowany model polityki personalnej, wakaty, trudności z pozyskaniem pracowników, wielkość przedsiębiorstwa i sektor). W modelach $\mathrm{w}$ wersji pełnej uwzględniono zatem 10 zmiennych objaśniających (po wyłączeniu grup referencyjnych).

Biorąc pod uwagę deklaracje respondentów dotyczące kwestii stanowiących podstawę wyodrębniania kategorii zmiennych objaśniających, należy stwierdzić, iż badane przedsiębiorstwa swoją politykę personalną realizowały głównie $\mathrm{z}$ wykorzystaniem modelu kapitału ludzkiego bądź modelu mieszanego (w miarę zrównoważony udział powyżej 40\%). Model sita stanowił podstawę polityki personalnej jedynie 7,8\% podmiotów. Z kolei $65,5 \%$ badanych podmiotów dysponowało wakatami, na wypełnienie których poszukiwało kandydatów. Pozostałe podmioty nie zgłaszały wolnych miejsc pracy, przy czym 59,2\% podmiotów wskazywało na trudności $z$ pozyskaniem pracowników, pozostałe przedsiębiorstwa takich trudności nie raportowały.

Biorąc pod uwagę charakterystyki wielkościowe i sektorowe badanych podmiotów, w przypadku pierwszej z wymienionych kategorii próba badawcza była $\mathrm{w}$ miarę zrównoważona (co było efektem zastosowanej procedury doboru podmiotów do niej). Każda kategoria podmiotów mniejszych niż duże reprezentowała ponad dwudziestoprocentowy udział, podmioty duże zaś stanowiły 7,8\% ogółu,

Tabela 2. Wykaz zmiennych objaśniających wtączanych do modelu 1

\begin{tabular}{|l|c|l|l|}
\hline \multicolumn{1}{|c|}{$\begin{array}{c}\text { Kategoria zmiennych } \\
\text { objaśniających }\end{array}$} & $\begin{array}{c}\text { Liczba } \\
\text { zmiennych }\end{array}$ & $\begin{array}{c}\text { Grupa } \\
\text { referencyjna }\end{array}$ & model kapitału ludzkiego, model mieszany \\
wealizowany model polityki personalnej & 3 & model sita & zgłaszanie wakatów \\
\hline wakaty & 2 & brak wakatów & brak trudności \\
\hline trudność z pozyskaniem pracowników & 2 & zgłaszanie trudności & małe, średnie, duże \\
\hline wielkość przedsiębiorstwa & 4 & mikro-przedsiębiorstwa & przemysł, usługi, administracja publiczna \\
\hline sektor & 4 & rolnictwo & \\
\hline
\end{tabular}

Źródło: opracowanie własne 
a $17,5 \%$ podmiotów nie zostało zaklasyfikowanych (brak deklaracji). W przekroju sektorowym w próbie badawczej dominowały podmioty usługowe (41\% przypadków), następnie podmioty publiczne (oświata, kultura ... - 26\% przypadków), 23,5\% ogółu stanowiły przedsiębiorstwa przemysłowe, zaś 5\% - rolnicze. Badane podmioty funkcjonowały zazwyczaj w formie spółki z ograniczoną odpowiedzialnością oraz jednoosobowej własności prywatnej (łącznie ponad 50\% przypadków).

Chęć zatrudniania w perspektywie najbliższych 6 miesięcy deklarowało $45 \%$ przedsiębiorstw, przy czym następuje istotne rozwarstwienie deklaracji podmiotów posiadających obecnie wakaty (w tej grupie chęć zatrudnienia w założonej perspektywie czasowej deklarowało $64,1 \%$ przedsiębiorstw) i niedysponujących wolnymi miejscami pracy (te przedsiębiorstwa nie widzą konieczności zatrudniania w założonej perspektywie czasowej - adekwatny odsetek wskazań analizowanej opcji to $8,7 \%)$.

W tabeli 3 zaprezentowano ilorazy szans określone na podstawie oszacowań parametrów modelu dla zmiennych istotnych statystycznie określonych w modelu zredukowanym (redukcja krokowa).

Sektor, w którym operuje przedsiębiorstwo, nie okazał się istotnym czynnikiem różnicującym prawdopodobieństwo korzystania $\mathrm{z}$ rozwiązań internetowych w rekrutacji. Podobnie (brak istotnych statystycznie związków) można rozpatrywać również aktualne zapotrzebowanie na pracę $\mathrm{w}$ badanych podmiotach (podmioty $\mathrm{w}$ tej kategorii zmiennych podzielono na dysponujące bądź niedysponujące wakatami).

W przypadku wszystkich grup podmiotów tworzonych poprzez pryzmat pozostałych kryteriów podziału populacji odnotowano istotne statystycznie zróżnicowanie $\mathrm{w}$ prawdopodobieństwie korzystania $\mathrm{z}$ rozwiązań internetowych w sferze rekrutacji. Przedsiębiorstwa deklarujące stosowanie w polityce personalnej modelu kapitału ludzkiego bądź modelu mieszanego dwukrotnie częściej wykorzystują tego typu rozwiązania niż przedsiębiorstwa opierające swoje rozwiązania $\mathrm{w}$ sferze personalnej o model sita. Badane podmioty różnicowano pod kątem deklarowanych (bądź nie) trudności $\mathrm{z}$ pozyskaniem pracowników na wakujące stanowiska pracy. Przedsiębiorstwa deklarujące brak takowych trudności równolegle w mniejszym zakresie stosują e-rozwiązania w sferze rekrutacji niż podmioty takie trudności raportujące (iloraz szans wyraźnie poniżej jedności). Ostatnim z rozpatrywanych kryteriów podziału populacji, gdzie odnotowano w wyodrębnionych grupach podmiotów związki istotne statystycznie, była wielkość przedsiębiorstwa. Można zaobserwować systematyczny wzrost szans na wykorzystanie e-rozwiązań w sferze rekrutacji wraz ze wzrostem wielkości podmiotu. W przedsiębiorstwach małych szanse są prawie dwukrotnie większe, średnich - ponad dwukrotnie większe, zaś w przypadku przedsiębiorstw dużych - już ponad czterokrotnie większe w stosunku do grupy referencyjnej (mikroprzedsiębiorstw).
Tabela 3. Ilorazy szans dla zmiennych istotnych statystycznie w modelu 1

\begin{tabular}{|l|c|}
\hline \multicolumn{1}{|c|}{ Zmienna objaśniająca } & Iloraz szans \\
\hline model kapitału ludzkiego & 2,27 \\
\hline model mieszany & 2,91 \\
\hline brak trudności z pozyskaniem pracowników & 0,53 \\
\hline małe & 1,83 \\
\hline średnie & 2,84 \\
\hline duże & 4,41 \\
\hline
\end{tabular}

Źródto: opracowanie wtasne

W drugim modelu zmienne objaśniające kodowano na podstawie wskazań respondentów na pozostałe z opcji, które mógł wybrać wypełniający kwestionariusz ankietowy w odpowiedzi na pytanie: $\mathrm{W}$ jaki sposób Państwa przedsiębiorstwo poszukuje pracowników? poza opcją kodowaną jako zmienna objaśniana. Próbowano określić w ten sposób, które z narzędzi rekrutacji są najczęściej bądź najrzadziej wykorzystywane przez badane podmioty równolegle $z$ instrumentami rekrutacji z wykorzystaniem Internetu. Strukturę deklaracji respondentów $\mathrm{w}$ odpowiedzi na analizowane pytanie, a zatem i wykaz wariantów rozpatrywanych jako podstawa kodowania zmiennych objaśniających zaprezentowano wcześniej w tabeli 1 przy okazji prezentacji założeń modelu 1.

Po przeprowadzeniu procedury krokowej redukcji zmiennych nieistotnych statystycznie $\mathrm{w}$ gronie zmiennych rozpatrywanych znalazły się dwie zmienne objaśniające. W tabeli 4 zestawiono je wraz $\mathrm{z}$ informacją o obliczonych dla tych zmiennych ilorazach szans.

Tabela 4. Ilorazy szans dla zmiennych istotnych statystycznie w modelu 2

\begin{tabular}{|l|c|}
\hline \multicolumn{1}{|c|}{ Zmienna objaśniająca } & Iloraz szans \\
\hline ogłoszenia w prasie & 3,13 \\
\hline pośrednictwo urzędów pracy & 0,35 \\
\hline
\end{tabular}

Źródto: opracowanie wtasne

Analizując dane w tym zestawieniu, należy stwierdzić, iż przedsiębiorstwa ogłaszające informacje o wolnych wakatach w Internecie prowadzą równoległą kampanię informacyjną w prasie (szanse na stosowanie tego typu rozwiązań są tu ponad trzykrotnie większe). Badania ukazały, iż podmioty korzystające z możliwości w sferze rekrutacji stwarzanych przez globalną sieć korzystają wyraźnie rzadziej z pośrednictwa urzędów pracy.

Analizom poddano jakość oszacowań prezentowanych modeli logitowych. Adekwatne miary zaprezentowano w tabeli 5 . 
Tabela 5. Miary oceny jakości modeli

\begin{tabular}{|l|c|c|}
\hline \multicolumn{1}{|c|}{ Miara oceny jakości modelu } & Model 1 & Model 2 \\
\hline R-kwadrat McFaddena & 0,084 & 0,094 \\
\hline \% przypadków poprawnej predykcji & 66,2 & 67,2 \\
\hline $\begin{array}{l}\text { \% przypadków poprawnej predykcji } \\
\text { sukcesu }\end{array}$ & 68,5 & 73,0 \\
\hline $\begin{array}{l}\text { \% przypadków poprawnej predykcji } \\
\text { porażki }\end{array}$ & 56,4 & 55,2 \\
\hline $\begin{array}{l}\text { współczynnik korelacji pomiędzy } \\
\text { wartościami empirycznymi } \\
\text { i teoretycznymi }\end{array}$ & $0,328^{*}$ & $0,336^{*}$ \\
\hline
\end{tabular}

* Wartości istotne statystycznie przy a = 0,05

Źródło: opracowanie własne

Biorąc pod uwagę większość parametrów, lepszą jakość można przyporządkować modelowi 2 (wyższe R-kwadrat, wyższe, jednakże nieznacznie w stosunku do modelu 1, odsetek poprawnej predykcji oraz współczynnik korelacji pomiędzy wartościami empirycznymi i teoretycznymi). Model 1 nieznacznie lepiej prognozuje prawdopodobieństwo porażki. Oba modele wyraźnie bardziej poprawnie określają prawdopodobieństwo sukcesu.

\section{Podsumowanie}

$\mathbf{P}$ odsumowując powyższe rozważania, należy stwierdzić, iż przeprowadzona analiza pozwoliła na sformułowanie kilku istotnych wniosków w kontekście postawionego celu pracy:

- Najczęściej wykorzystywanym narzędziem przekazywania informacji o wolnych miejscach pracy w badanych podmiotach były ogłoszenia udostępniane w Internecie.

- Przedsiębiorstwa swoją politykę personalną realizowały głównie $\mathrm{z}$ wykorzystaniem modelu kapitału ludzkiego, a trochę rzadziej modelu mieszanego.

- Przedsiębiorstwa deklarujące stosowanie w polityce personalnej modelu kapitału ludzkiego bądź modelu mieszanego wyraźnie częściej wykorzystywały Internet do rekrutacji niż przedsiębiorstwa opierające swoje rozwiązania w sferze personalnej o model sita.

-W miarę wzrostu swojej wielkości przedsiębiorstwa wyraźnie częściej wykorzystywały Internet jako narzędzie rekrutacji.

- Korzystanie z rozwiązań e-rekrutacji nie było zależne od sektora, w którym operowały badane podmioty.

- Przedsiębiorstwa ogłaszające informacje o wolnych wakatach w Internecie prowadziły równoległa kampanię informacyjną w prasie, traktując zatem instrumentarium e-rekrutacji jako komplementarne wobec rekrutacji tradycyjnej.

- Podmioty korzystające z możliwości w sferze rekrutacji stwarzanych przez globalną sieć korzystały wyraźnie rzadziej z pośrednictwa urzędów pracy. Po stronie ograniczeń interpretacji wyników badań należy wskazać: subiektywizm deklaracji respondentów, ograniczenie, ze względów technicznych, liczby możliwych do wyboru opcji prezentujących alternatywne instrumentarium poszukiwania pracy, włączenie do analiz zmiennych objaśniających możliwych do zakodowania na bazie dostępnego materiału empirycznego (brak odzwierciedlenia równoległego wpływu wielu innych istotnych czynników) czy zawężenie zakresu rozpatrywanych grup w ujęciu sektorowym (ze względu na niską liczebność wybranych grup wyodrębnionych na podstawie sektora, w którym funkcjonują).

Jako kierunki dalszych badań można wskazać: włączenie do analiz innych zmiennych - charakterystyk badanych podmiotów (modele wyjaśniają relatywnie niewielki fragment zmienności), np. forma własności, forma organizacyjna, rozszerzenie analiz poza szczebel makrosektora bądź inne czynniki oraz rozszerzenie adekwatnych analiz w kierunku poznania struktury wykorzystywanego instrumentarium e-rekrutacji (w tym $\mathrm{z}$ uwzględnieniem instrumentarium ukierunkowanego na media społecznościowe) oraz determinant sprzyjających wykorzystaniu poszczególnych instrumentów.

\section{dr hab. Wojciech Jarecki, prof. uczelni Uniwersytet Szczeciński Wydział Nauk Ekonomicznych i Zarządzania ORCID: 0000-0002-4463-7607 e-mail: wojciech.jarecki@usz.edu.pl}

\section{dr hab. Marek Kunasz, prof. uczelni Uniwersytet Szczeciński Wydział Nauk Ekonomicznych i Zarządzania ORCID: 0000-0002-1577-0425 e-mail: marek@kunasz.eu}

\section{Przypis}

1) W pracy wykorzystano materiał empiryczny zgromadzony w ramach badań ankietowych przedsiębiorstw przeprowadzonych podczas realizacji projektu badawczego „Aktywizacja zawodowa i badawcza Uniwersytetów Trzeciego Wieku”. Projekt był realizowany przez Uniwersytet Szczeciński, a finansowany ze środków Ministerstwa Nauki i Szkolnictwa Wyższego.

\section{Bibliografia}

[1] Cichy K. (2008), Kapitał ludzki i postęp techniczny jako determinanty wzrostu gospodarczego, Instytut Wiedzy i Innowacji, Warszawa.

[2] Frandsen M., Thow M., Ferguson S.G. (2016), The Effectiveness of Social Media (Facebook) Compared with More Traditional Advertising Methods for Recruiting Eligible Participants to Health Research Studies: A Randomized, Controlled Clinical Trial, „Journal of Medical Internet Research", No. (5)/3, e. 161, https://www.researchprotocols. org/2016/3/e161/, access date: 12.05.2019. 
[3] Górecki B.R. (2010), Ekonometria. Podstawy teorii i praktyki, Key Text, Warszawa.

[4] Gruszczyński M. (red.), (2012), Mikroekonometria. Modele i metody analizy danych indywidualnych, Wolters Kluwer, Warszawa.

[5] GUS (2019), Jak korzystamy z Internetu? https://stat. gov.pl/obszary-tematyczne/nauka-i-technika-spoleczenstwo-informacyjne/spoleczenstwo-informacyjne/ jak-korzystamy-z-internetu-2018,5,9.html, data dostępu: 12.05.2019 r.

[6] Ihsan Z., Furnham A. (2018), The New Technologies in Personality Assessment, „Consulting Psychology Journal: Practice and Research", Vol. 70, No. 2, pp. 147-166.

[7] Jarecki W. (2011), Szacowanie kosztów i efektów ksztatcenia ekonomicznego na poziomie wyższym, Wydawnictwo Naukowe Uniwersytetu Szczecińskiego, Szczecin.

[8] Juchnowicz M. (red.), (2007), Elastyczne zarządzanie kapitałem ludzkim $w$ organizacji wiedzy, Difin, Warszawa.

[9] Kadry.infor (2018), https://kadry.infor.pl/kadry/hrm/ rekrutacja/786095, Media-spolecznosciowe-w-procesie-rekrutacji.html, data dostępu: 19.06.2018 r.

[10] Kiełtyka L., Zygoń O. (2018), Współczesne formy komunikacji - jak zarządzać $z$ wykorzystaniem Internetu Rzeczy $i$ Wszechrzeczy, „Przegląd Organizacji”, Nr 2, s. 24-32.

[11] Kłosiński K. (2018), Rola Social Media w procesach rekrutacji HR, https://hrownia.pl/artykuly/rola_social_media_w_procesach_rekrutacji, data dostępu: 27.02.2018 r.

[12] Kufel T. (2011), Ekonometria - rozwiązywanie problemów z wykorzystaniem programu GRETL, Wyd. Naukowe PWN, Warszawa.

[13] Lee J.-M., Rha J.-Y. (2016), Personalization, Privacy Paradox and Consumer Conflict with the Use of Location-based Mobile Commerce, "Computers in Human Behaviour”, No. 63, pp. 453-462.

[14] Maddala G.S. (2013), Ekonometria, Wyd. Naukowe PWN, Warszawa.

[15] Młokosiewicz M., Misiak-Kwit S. (2017), The Impact of Trust on Entrepreneurship in Poland, „Journal of Entrepreneurship, Management and Innovation", Vol. 13, No. 4, pp. 79-95.

[16] Mroczek P. (2018), https://grupaprogres.pl/rekrutacja-przez-social-media-czyli-o-nowych-sposobach-pozyskiwania-pracownikow/, data dostępu: 14.09.2018 r.

[17] Ngai E.W.T., Tao S.S.C., Moon K.K.L. (2015), Social media research: theories, constructs, and conceptual frameworks, „International Journal of Information Management”, Vol. 35, No. 1, pp. 33-44.

[18] Olszak C.M. (2018), Tworzenie wartości biznesowej z wykorzystaniem zasobów Big Data, „Przegląd Organizacji”, Nr 7, s. 37-40.

[19] Osińska M. (red.), (2007), Ekonometria współczesna, Dom Organizatora, Toruń.

[20] Ouirdi M., Ouirdi A., Segers J., Pais I. (2016), Technology Adoption in Employee Recruitment: The Case of Social Media in Central and Eastern Europe, „Computers in Human Behaviour”, Vol. 57, pp. 240-249.
[21] Schaupp L.C., Bélanger F. (2014). The Value of Social Media for Small Businesses, „Journal of Information Systems", Vol. 28, No. 1, pp. 187-207.

[22] Smentek D. (2007), Management of an Ageing Workforce. How Employers Candeal with Related Challenges, VDM, Saarbrücken.

[23] Social Recruiting Guide (2016), How to Effectively Use Social Networks, An Oracle White Paper, Julay 2012; „The Benefits of Social Recruiting”, http://www. jobcast.net/benefits-of-socialrecruiting, access date: 12.06.2016.

[24] Urbanowska-Sojkin E., Weinert A. (2019), Wykorzystanie systemów IT $w$ informacyjnym wspomaganiu wyborów strategicznych $w$ przedsiębiorstwach działajacych $w$ różnych sektorach, „Przegląd Organizacji”, Nr 4, s. $58-67$.

[25] Wadle L-M., Martin N., Ziegler D. (2019), Privacy and Personalization: The Trade-off between Data Disclosure and Personalization Benefit, Proceedings UMAP'19 Adjunct Adjunct Publication of the 27th Conference on User Modeling, Adaptation and Personalization, Larnaca, pp. 319-324.

[26] Welfe A. (2009), Ekonometria. Metody i ich zastosowanie, PWE, Warszawa.

[27] Wielgórska E. (2018), CV odchodzi do lamusa, http:// www.ekonomia24.pl/artykul/920786.html, data dostępu: 27.05.2018 r.

[28] Woźniak J., Rafalik M. (2018), Postrzeganie uczciwości nowych i tradycyjnych narzędzi selekcyjnych, „Humanizacja Pracy", Nr 4, s. 61-77.

\section{Factors Determining the Use of the Internet in Recruiting New Employees in Enterprises from West Pomeranian Voivodship}

\section{Summary}

The paper aims to identify factors determining the use of the Internet in recruiting new employees. The empirical part of the paper presents the results of a survey distributed among 203 enterprises from the West Pomeranian voivodship. The survey was conducted with the use of instruments available as part of econometric modelling (logit models are estimated). The survey suggests that the Internet is the channel most often used for the distribution of information about job vacancies. Furthermore, the model of HR policy and the size of enterprise are factors that have the most profound effect on enterprises' activity as far as e-recruitment is concerned. With reference to the enterprises responding to the survey, the use of e-recruitment solutions is not sector-related.

\section{Keywords}

human capital management, recruitment, e-recruitment, IT 